\title{
Soil color sensor data collection using a GPS-enabled smart-
}

\section{phone application}

Roxanne Stiglitz ${ }^{\mathrm{a}}$, Elena Mikhailova ${ }^{\mathrm{a},{ }^{*}, \text { Christopher Post }}{ }^{\mathrm{a}}$, Mark

Schlautman $^{\mathrm{b}}$, Julia Sharp ${ }^{\mathrm{c}}$, Roy Pargas ${ }^{\mathrm{d}}$, Benjamin Glover $^{\mathrm{d}}$, Jack Mooney ${ }^{\mathrm{d}}$

${ }^{a}$ Department of Forestry and Environmental Conservation, Clemson University,

Clemson, 29634, SC, USA

${ }^{\mathrm{b}}$ Department of Environmental Engineering and Earth Sciences, Clemson University, Clemson, 29634, SC, USA

${ }^{\mathrm{C}}$ Department of Statistics, Colorado State University, Fort Collins, 80523, CO, USA

${ }^{\mathrm{d}}$ School of Computing, Clemson University, Clemson, 29634, SC, USA

Corresponding author. Current address: Department of Forestry and Environmental

Conservation, Clemson University, 261 Lehotsky Hall, Clemson, SC 29634, USA. Tel.

864-656-3535, Fax: 864-656-3304.

Email address: eleanam@clemson.edu (E.A. Mikhailova). 


\section{ABSTRACT}

Application of accurate and low-cost sensor technology to collect soil color data provides an opportunity to increase the density, quality and quantity of soil data to monitor our changing soil resources. The objective of this study was to develop a mobile application that would enable users to create their own soils database consisting of GPS location and soil color data gathered using the application and a mobile sensor. A mobile application was created utilizing the $\mathrm{Nix}^{\mathrm{TM}}$ Pro color sensor that produces multiple color results, including Munsell color notation. The application also allows users to toggle between "in-field" sampling as well as dry or moist soil samples. Users can choose to record GPS location and a photo of the soil sample to upload into an online database for storage. The application was tested for functionality in the field and for its ability to match Munsell notation values determined using a Munsell Soil Color Chart (MSCC). Field data were synchronized to a cloud database and subsequently retrieved and used to produce a Geographic Information Systems (GIS) layout showing sample point locations and soil color attributes. The Soil Scanner application allows for rapid analysis and collection of soils data that can be stored for further study and reference using various color systems and location data.

Keywords: Cloud storage, Geographic Information Systems (GIS), Munsell color chart, Spatial, Soil classification, Soil survey 


\section{Introduction}

Soil color is an important property used by the USDA Natural Resources Conservation Service (NRCS) to describe soils and it can be a strong indicator of other soil properties such as iron and organic matter contents (Lynn and Pearson, 2000; Sugita and Marumo, 1996). The Munsell soil solor chart (MSCC) notation, which commonly is used to describe soil color, often can be found in soil series descriptions and online databases provided by the NRCS to help characterize and describe soil horizons (Soil Survey Staff, 2016). Studies have shown that there are discrepancies in the printing quality of MSCC color chips as well as a strong potential for fading that can make the charts unreliable (Sanchez-Maranon et al., 2005; Viscarra Rossel et al., 2006), yet the MSCC has been the standard in-field method of soil color determination for decades (Shields et al., 1965). The color charts also are more qualitative than quantitative, leading many soil scientists to turn to alternative methods of color analysis (Kirillova et al., 2014). Instruments such as spectrophotometers and colorimeters often are used in lieu of a MSCC (Thompson et al., 2013); however, these instruments can be expensive and may require an external power source which makes in-field color determination very difficult. More recently, scientists have been testing and creating new methods of color determination that are more field-friendly as well as less expensive (Levin et al., 2005).

Stiglitz et al. (2016a) tested a new and inexpensive color sensor, the $\mathrm{Nix}^{\mathrm{TM}}$ Pro, as a mobile method of soil color determination. The $\mathrm{Nix}^{\mathrm{TM}}$ Pro sensor is controlled via Bluetooth $^{\circledR}$ and a mobile app through a smartphone. Multiple soil samples were analyzed for color in moist and dry soil conditions and indoor and outdoor lighting. The $\mathrm{Nix}^{\mathrm{TM}}$ Pro 
color values were compared to MSCC as well as a Konica Minolta CR-400 laboratory colorimeter. The results showed that the $\mathrm{Nix}^{\mathrm{TM}}$ Pro produced repeatable readings and that the color values of the $\mathrm{Nix}^{\mathrm{TM}}$ Pro and Konica Minolta CR-400 were very similar. Stiglitz et al. (2016) concluded that the $\mathrm{Nix}^{\mathrm{TM}}$ Pro would be a good alternative to the MSCC as an in-field soil color determination method. However, the application used to control the Nix ${ }^{\mathrm{TM}}$ Pro is not directed towards the field of soil science. Ideally, the application would allow for data storage and produce MSCC notation as well because it is the most commonly used color system.

In a study by Gomez-Robledo et al. (2013) a cellphone application was created to determine the color of soil samples from pictures taken with the cell phone camera. Software was developed to scan the pixels in the soil sample pictures taken by the camera and convert the subsequent red, green, and blue (RGB) color values to digital red, green, and blue (XYZ) and to Munsell hue, value, and chroma (HVC). The results were promising and demonstrated that cellphone cameras and a simple color conversion application can be utilized as effective soil color sensors. Han et al. (2016) also used a smartphone camera to process color images of soil samples. After processing the RGB values obtained from the images, it was once again concluded that cellphone cameras are effective at determining soil color. Han et al. (2016) were able to accurately classify soils based on this data, however, it was noted that differences in cellphone hardware may result in a change in accuracy of results and software stability. Furthermore, environmental factors such as soil moisture and lighting conditions would still affect the study results. 
Regardless of the drawbacks of cellphone cameras, these mobile devices have proven to be a useful tool in soil science and related fields. Beaudetter and O'Geen (2010) developed an iPhone application to deliver on-demand access to soil survey information from any location with cellphone coverage. Migliaccio et al. (2015) proposed the turf irrigation application that develops recommended irrigation schedules based on inputs of form data and real-time weather data. User input data includes soil type (texture) information as well as location and rooting depth. Soil texture information is used to assign estimated field capacity. Other user inputs include information about the field area and sprinkler type (to indicate water rate). Real-time weather data, including temperature, humidity, solar radiation, and wind speed are used to estimate water loss through evapotranspiration (ET). The application was shown to reduce overall water usage when compared to time-based irrigation schedules. Bartlett et al. (2015) created a smartphone application for an irrigation scheduling tool on a cloud-based server.

Mobile technologies are advancing soil science as new applications and analysis methods are created. In addition, new technologies provide opportunities for outreach and raising awareness of many scientific issues faced today as mobile technologies are becoming more widely available and affordable (Ciampitti and McCornack, 2016). With development of new mobile devices and applications, subjects such as soil quality can be readily studied, not only by professionals but also by students in classroom settings (Karlen et al., 2003). To ensure that new applications are efficient learning tools in the classroom, Isrealson (2015) proposed "the App Map" which is a basic rubric for judging the effectiveness of an application. In general, if a mobile application would function 
well in a classroom setting and improve knowledge of an area of science, then it would also function well in field settings.

Mobile devices offer the opportunity to quickly and easily analyze certain soil properties. However, current mobile applications commonly face limitations based on the device and environmental conditions. There should be one set device capable of running analysis on soils through an application that would allow for constantly updating soils data and storage. Finally, the application and device should be user friendly and inexpensive. As such, the objective of this study was to create an Android-based application capable of working with the $\mathrm{Nix}^{\mathrm{TM}}$ Pro color sensor that would: (i) produce cyan, magenta, yellow, and black (CMYK), XYZ, RGB, CIELab, and MSCC color values, (ii) record GPS locations, and (iii) upload collected data to a constantly updating Cloud databank.

\section{Materials and methods}

\subsection{Developing the color application}

Development of the Soil Scanner mobile application was completed using Google's integrated development environment (IDE) software, Android Studio 2.0, to compile and edit the code for the application. Java was chosen as the programming language and the Android software development kit (SDK) was used to develop the application into Android friendly software. Access to the Nix ${ }^{\mathrm{TM}}$ Pro application program interface (API) was provided by the Nix ${ }^{\mathrm{TM}}$ Pro development team allowing for smoother 
integration of the already-existing color sensing functions of the sensor into the Soil Scanner application. The original $\mathrm{Nix}^{\mathrm{TM}}$ Pro application is free to download and the Soil Scanner application will also be free to download upon finalization.

Upon completion, the application was able to connect to a $\mathrm{Nix}^{\mathrm{TM}}$ Pro color sensor, download a Munsell color reference table, and scan soil samples for color (Fig. 1). Resulting color systems include CMYK, CIELab, XYZ, RGB, and Munsell notations. Users have the option to choose whether the samples were analyzed in a field setting and if the soil samples are dry or moist. Choosing the field setting option enables the user to obtain the GPS location of the sample. In addition, the user has the option to take a reference photo of soil samples using the mobile device's camera to be saved with all other collected data, though a photograph is not required (Fig. 2). Recently scanned data will appear within the application and the user has the option of uploading all data to an online database for storage (Fig. 3).

\subsection{Integration of color systems into the color application}

The Nix ${ }^{\mathrm{TM}}$ Pro API included code to produce CMYK, CIELab, XYZ, and RGB color results as default color systems within the Soil Scanner application. A goal was to include Munsell color notation as well to coincide with current soil science standards for soil descriptions. An external Munsell database that contained the equivalent RGB and CIELab color values for each Munsell HVC was developed from preexisting data gathered from WallkillColor (2006). Missing Munsell values were found using BabelColor software (BabelColor, 2015). Only Munsell values found in the Munsell Soil 
Color Chart were used. Using this database, an algorithm was used to determine the closest RGB or CIELab to Munsell color matches by calculating the Euclidean distance of the color resulting values. This method produced three Munsell notations with the shortest Euclidean distance from the analyzed soil sample color. The resulting three Munsell notations correlate to the closest matching colors. From the interface, the closest Munsell color value can be viewed and chosen from three resulting color swatches that accompany the color systems (Fig. 2).

\subsection{Testing the color application}

Once the development of the Soil Scanner application was completed, the functionality and accuracy of the Munsell color results were tested. The default CMYK, CIELab, XYZ, and RGB color results of the Nix Pro API were not altered; therefore, it was not necessary to test the accuracy of these results because the Nix Pro sensor has

previously been demonstrated to produce reliable color results (Stiglitz et al., 2016a). The cellphone used for the experiment was a Samsung Galaxy S6 Edge running Android version 5.1.1 with a camera resolution of 16 megapixels. Thirty-one oven-dried, crumble, soil samples that were collected at varying depths from thirteen soil pits, as described in Stiglitz et al. (2016a), were analyzed for Munsell color using the $\mathrm{Nix}^{\mathrm{TM}}$ Pro color sensor, the Soil Scanner application, and a smartphone used only to control the application through Bluetooth connection (Fig. 4). The resulting Munsell notations were compared to Munsell notations previously determined by NRCS staff for moist samples and one researcher for dry samples using the MSCC for each soil sample (Table 1). The 
Euclidean distance for each soil sample was calculated to determine the effectiveness of the application to match human perceived color using a MSCC.

The original soil pits used to gather the thirty-one samples utilized for the color analysis were filled to continue agricultural production on the Simpson Agricultural Experiment Station in Pendleton, South Carolina and could not be used for GIS mapping. Therefore, a GIS map was generated using GPS locations and soil color data for additional surface sample locations (Fig. 5) located at the Station to determine the functionality of the application. Soil scans were located based on the cell phone GPS and attributes from the color sensor were imported into a GIS system. Point locations were interpolated using Inverse Distance Weighting to create a surface map of the a* (Fig. 5; greed to red) values for Simpson Agricultural Experiment Station samples and L* (Fig. 6; darkness to lightness) values for Willsboro Farm samples from the CIELab color data. Soils found at the sample locations are predominantly Ultisols and include Cecil clay loam, Pacolet sandy loam, Cartecay-Chewacla complex, Hiwassee sandy loam, and Cecil sandy loam as described by Stiglitz et al. (2016a) and have a geographic range from Georgia to Virginia, south to north, and from the eastern coast to Alabama, Tennessee, and Kentucky. These soil series are abundantly found along the Blue Ridge Mountains, Piedmont, and Valley and Ridge regions of the eastern United States (Stiglitz et al., 2016b).

In addition, 264 dry, crumble soil samples collected from the Willsboro Farm located in Willsboro, NY were analyzed for color using the Soil Scanner application and the resulting three Munsell notations were compared to the previously determined Munsell notation that was determined by one researcher using a MSCC. The soils located 
on the Willsboro Farm are of glacial till origin and are located in a lacustrine plain. Soil series include Bombay, Churchville, Covington, Howard, Kingsbury, Claverack, Cosad, Deerfield, Stafford, Amenia, Massena, and Nellis and can be categorized into Alfisols, Entisols, and Inceptisols soil orders (Mikhailova et al., 1996). Again, the Euclidean distance was determined for each of the three sensor determined Munsell notations in comparison to the visually determined Munsell notations. A GIS map (Fig. 6) was generated of the sample locations to map the variance of soil color across the study area.

\section{Results and discussion}

\subsection{Soil color application measurements}

The Euclidean distance between previously determined MSCC color (actual MSCC color) for each soil sample was compared to the three measured MSCC colors for each soil sample using the Soil Scanner application. Results showed that, for Simpson Agricultural Experiment Station samples, the first measured MSCC color for dry soils was, on average, two color chips away from the known MSCC color (standard deviation $(\mathrm{SD})=0.96)$. The second and third measured MSCC colors for dry soils were, on average, three color chips away ( $\mathrm{SD}=1.21$ and $\mathrm{SD}=1.54$, respectively). The first measured MSCC color for moist soils was, on average, two color chips away from the known MSCC color $(\mathrm{SD}=2.06)$. The second measured MSCC color for moist soils was, on average, three color chips away from the known MSCC color $(\mathrm{SD}=1.97)$. The third 
measured MSCC color for moist soils was, on average, four color chips away from the known MSCC color (SD = 3.28; Table 2).

For dry samples taken from the Willsboro Farm, the first measured MSCC color was, on average, three color chips away from the known MSCC color $(\mathrm{SD}=1.05)$. The second and third measured MSCC colors were, on average, four color chips away (SD = 1.99 and $\mathrm{SD}=2.31$ respectively; Table 3 ). When considering that the human eye was used to perceive the known soil sample color using a MSCC and that multiple participants determined the MSCC color of each sample, these results were to be expected. Past studies have shown that the human eye perceives color differently from person to person and in various illuminations (Villafuerte and Negro, 1998) and matching MSCC color chips can result in calculated differences of three MSCC units (SanchezMaranon et al., 2011). In a recent study by Han et al., (2016) a smartphone based camera was used for soil classification by using machine learning to analyze the soil color, but differences in illumination as well as variation is smartphone camera sensors was highly variable. In contrast, this study uses a Bluetooth linked color sensor with a standardized light source and sensing hardware which controls for light and sensor differences rather than relying on pixels in a photo taken by the smartphone itself.

\subsection{Potential uses and future directions}

Simplified and accurate soil color determination, using a low-cost color sensor interfaced to a smartphone application, can enhance data quality while also adding sample location information (through GPS). Having location information associated with 
the color data increases the value of this data and may help update soil spatial databases. While there are limitations in the accuracy of a smartphone GPS, it is also possible to improve location data by using an external Bluetooth GPS with the application. The ability to include a geo-referenced photo adds both context and a check on data-quality to a soil color reading. Soil color information is provided in the standard Munsell notation, and also in other color systems that are easier to use in quantitative comparisons. Cloud storage of soil color and sample attribute data provides a way to back up the data, but an internet connection is not required during sampling (which can reduce the cost of data acquisition).

Using an application and sensor also increases the speed of soil color sampling; so a much larger number of samples is possible, which further will enable both statistical comparisons as well as studies that examine the spatial variability of soil color (and the associated soil properties). Past studies have shown that soil color data allow for rapid assessment of soil organic matter (Bartholomeus et al., 2008; Stiglitz et al., 2016b). There is also potential to predict other soil attributes, such as metal oxides and depth to water table, as soil color is heavily influenced by these traits (Franzmeier et al., 1983; Schwertmann, 1993). The soil samples taken from the Simpson Agricultural Station for color analysis were high in iron content, and therefore appeared very red in color. Statistical comparisons between the Soil Scanner color data and laboratory determined iron content data could result in iron prediction models based on soil color.

Figure 5 shows an interpolation map of the $\mathrm{a}^{*}$ (red) value from the CIELab color data gathered from the surface scans on the Simpson Agriculture Experiment Station. The map appears to show a gradient of red from the left to the right of the map suggesting that 
the soils lose red intensity from the left to the right of the map. This gradient suggests that the left side of the map has a higher iron concentration that gradually decreases towards the right side of the map. Figure 6 shows an interpolation map of the L* (darkness to lightness) value from the CIELab color data gathered from the surface scans on the Willsboro Farm. The map shows locations that are much lighter in color which also appear as a lighter color on the map. The lighter color suggests that these areas may be more highly eroded compared to the other darker locations as past studies have shown that soils that appear lighter in color tend to be more eroded (Metternicht and Farmont, 1998). Data uploaded to cloud storage can be subsequently downloaded and plotted in GIS for spatial visualization and analysis. Soil Scanner data can be analyzed in this way for multiple soil components that could assist in generating soil erosion, fertility, and moisture maps using GIS software.

Current efforts in soil science application development include the successful sharing of spatial soil databases (e.g. SSURGO) through smartphone applications based on the location reported by the internal phone GPS (Beaudette and O'Geen, 2010). These efforts have shown the ability of applications to provide detailed soils data while users are in the field. This dramatically improves the potential impact of the soils databases by providing context to field surveys. Future developments of the soil color application may include a similar methodology to not only provide sensor-based color measurements, but also soils information from these internet-enabled databases. Another advantage of smartphone based applications is that it is possible to organize data collection using a series of custom drop-down menus and forms so that detailed information can be collected with as few errors as possible (Hansen et al., 2016). The soil color application 
may be extended in the future to include data entry options for other soil and land cover attributes to further augment spatial databases.

\section{Conclusions}

A mobile application for gathering soil color and GPS data that uses information from a Bluetooth paired commercial color sensor was developed and tested in field and laboratory settings. Sensor data, photos and location information are stored on the local Android device and subsequently synced to a cloud database where it can be retrieved at a later time. The mobile application reports multiple color results, including Munsell Soil Color Chart (MSCC). The application also allows users to toggle between "in-field" sampling as well as dry or moist soil samples. The application was tested for functionality in the field as well as its ability to match Munsell notation values determined using MSCC. Cloud-stored data can be downloaded and used in GIS analysis of point locations and soil color attributes. The Soil Scanner application provides the opportunity to increase the spatial density of accurate soil color measurements for soil classification and interpretation. 


\section{Acknowledgments}

Clemson University provided funding for this study. Technical Contribution No. 6432 of the Clemson University Experiment Station. This material is based upon work supported by NIFA/USDA, under project numbers SC-1700452, and SC-1700462. The authors would like to acknowledge Corey Stiglitz for his assistance. 


\section{References}

BabelColor, 2015. BabelColor: color measurement and analysis.

( http://www.babelcolor.com/)

Bartholomeus, H.M., Schaepman, M.E., Kooistra, L., Stevens, A., Hoogmoed, W.B., Spaargaaren, O.S.P., 2008. Spectral reflectance based indices for soil organic carbon quantification. Geoderma 145, 28-36.

Bartlett, A.C., Andales, A.A., Arabi, M., Bauder, T.A., 2015. A smartphone app to extend use of a cloud-based irrigation scheduling tool. Comput. Electron. Agric. 111, 127-130.

Beaudette, D.E., O’Geen, A.T., 2010. An iPhone application for on-demand access to digital soil survey information. Soil Sci. Soc. Am. J. 74(5), 1682-1684.

Ciampitti, I.A., McCornack, B.P., 2016. Customizing communication in our professional societies. CSA News: Career \& Education. p. 32-34.

Franzmeier, D.P., Yahner, J.E., Steinhardt, G.C., Sinclair, H.R., 1983. Color patterns and water table levels in some Indiana soils. Soil Sci. Soc. Am. J. 47(6), 1196-1202.

Gomez-Robledo, L., Lopez-Ruiz, N., Melgosa, M., Palma, A., Fermin CapitanVallvey, L., Sanchez-Maranon, M., 2013. Using the mobile phone as Munsell soil-colour sensor: An experiment under controlled illumination conditions. Comput. Electron. Agric. 99, 200-208.

Han, P., Dong, D., Zhao, X., Jiao, L., Lang, Y., 2016. A smartphone-based soil color sensor: For soil type classification. Comput. Electron. Agric. 123, 232-241. 
Hansen, M., Petersen, M.N., Kokfelt, T.F., Stensgaard, B.M., 2016. aFieldWork - an Android app for offline recording of geological information and data display. Geol. Surv. Den. Greenl. Bull. 35, 99-102.

Israelson, M.H., 2015. The App Map. The Reading Teacher 69 (3), 339-349.

Karlen, D.L., Ditzler, C.A., and Andrews, S.S., 2003. Soil quality: Why and how? Geoderma 114, 145-156.

Kirillova, N.P., Vodyanitskii, Y. N., Sileva, T.M., 2014. Conversion of soil color parameters from the Munsell System to the CIE-L*a*b* System. Eurasian Soil Sci. 48 (5), 468-475.

Levin, N., Ben-Dor, E., Singer, A., 2005. A digital camera as a tool to measure colour indices and related properties of sandy soils in semi-arid environments. Int. J. Remote Sens. 26 (24), 5475-5492.

Lynn, W.C., Pearson, M.J., 2000. The color of soil. The Science Teacher 67 (5), 20-23. Metternicht, G.I., Fermont, A., 1998. Estimating erosion surface features by linear mixture modeling. Remote Sens. Environ. 64 (3), 254-265.

Migliaccio, K.W., Morgan, K.T., Fraisse, C., Vellidis, G., Andreis, J.H., 2015. Performance evaluation of urban turf irrigation smartphone app. Comput. Electron. Agric. 118, 136-142.

Mikhailova, E. A., Van Es, H. M., Lucey, R. F., DeGloria, S. D., Schwager, S. J. and C. J. Post. 1996. Soil Characterization Data for Selected Pedons from the Willsboro Farm, Essex County, New York. Research Series R96-5. Department of Soil, Crop, and Atmospheric Sciences, Cornell University, Ithaca, New York 14853. 
Sanchez-Maranon, M., Garcia, P.A., Huertas, R., Hernandez-Andres, J., Melgosa, M., 2011. Influence of natural daylight on soil color description: Assessment using a color-appearance model. Soil Sci. Soc. Am. J. 75, 984-993.

Sanchez-Maranon, M., Huertas, R., and Melgosa, M., 2005. Colour variation in standard soil-colour charts. Aust. J. Soil Res. 43, 827-837.

Schwertmann, U., 1993. Relations between iron oxides, soil color and soil formation. In: Bigham, J.M., Coilkosz, E.J. (Eds.), Soil Color Vol. 31. Soil Science Society of America (SSSA), Madison, WI., pp. 51-69 SSSA Spec. Publ.

Shields, J.A., Arnaud, R.J. St., Paul, E.A., Clayton, J.S., 1965. Measurement of soil color. Can. J. Soil. Sci. 46, 83-90.

Soil Survey Staff, 2016. Web Soil Survey. Natural Resources Conservation Service, United States Department of Agriculture. Web Soil Survey. (http://websoilsurvey.sc.egov.usda.gov/App/HomePage.htm.)

Stiglitz, R., Mikhailova, E., Post, C., Schlautman, M., Sharp, J., 2016. Evaluation of an inexpensive sensor to measure soil color. Comput. Electron. Agric. 121, 141-148.

Stiglitz, R., Mikhailova, E., Post, C., Schlautman, M. Sharp, J., 2016. Using an inexpensive color sensor for rapid assessment of organic carbon. Geoderma 286, 98-103.

Sugita, R., Marumo, Y., 1996. Validity of color examination for forensic soil identification. Forensic Sci. Int. 83, 201-210.

Thompson, J., Pollio, A., Turk, P., 2013. Comparison of Munsell soil color charts and the GLOBE soil color book. Soil Sci. Soc. Am. J. 77, 2089-2093. 
Villafuerte, R., Negro, J.J., 1998. Digital imaging for colour measurement in ecological research. Ecol. Lett. 1, 151-154.

Viscarra Rossel, R.A., Minasny, B., Roudier, P., McBratney, A.B., 2006. Colour space models for soil science. Geoderma 133, 320-337.

WallkillColor. 2006. Munsell Conversion Data Tables.

(http://wallkillcolor.com/index2.htm). 


\section{List of Figures}

Fig. 1. Functional diagram of the Color Scanner application which shows the process of scanning a soil sample for color from start to finish.

Fig. 2. Example of the Soil Scanner interface that shows all possible color system values for a soil sample and options for "Field Mode," "Dry" soil, GPS location, and attaching a photo of the soil sample.

Fig. 3. Example of stored soil scan data using the Soil Scanner application.

Fig. 4. Example of a soil surface being scanned using the Nix Pro color sensor.

Fig. 5. GIS layouts showing: scan locations (top), soil color attributes (middle), and interpolated $\mathrm{a}^{*}$ (red) color values using Inverse Distance Weighting (bottom) for the Simpson Agricultural Experiment Station.

Fig. 6. GIS layout showing scan locations and interpolated $\mathrm{L}^{*}$ (darkness to lightness) color values using Inverse Distance Weighting for the Willsboro Farm. 


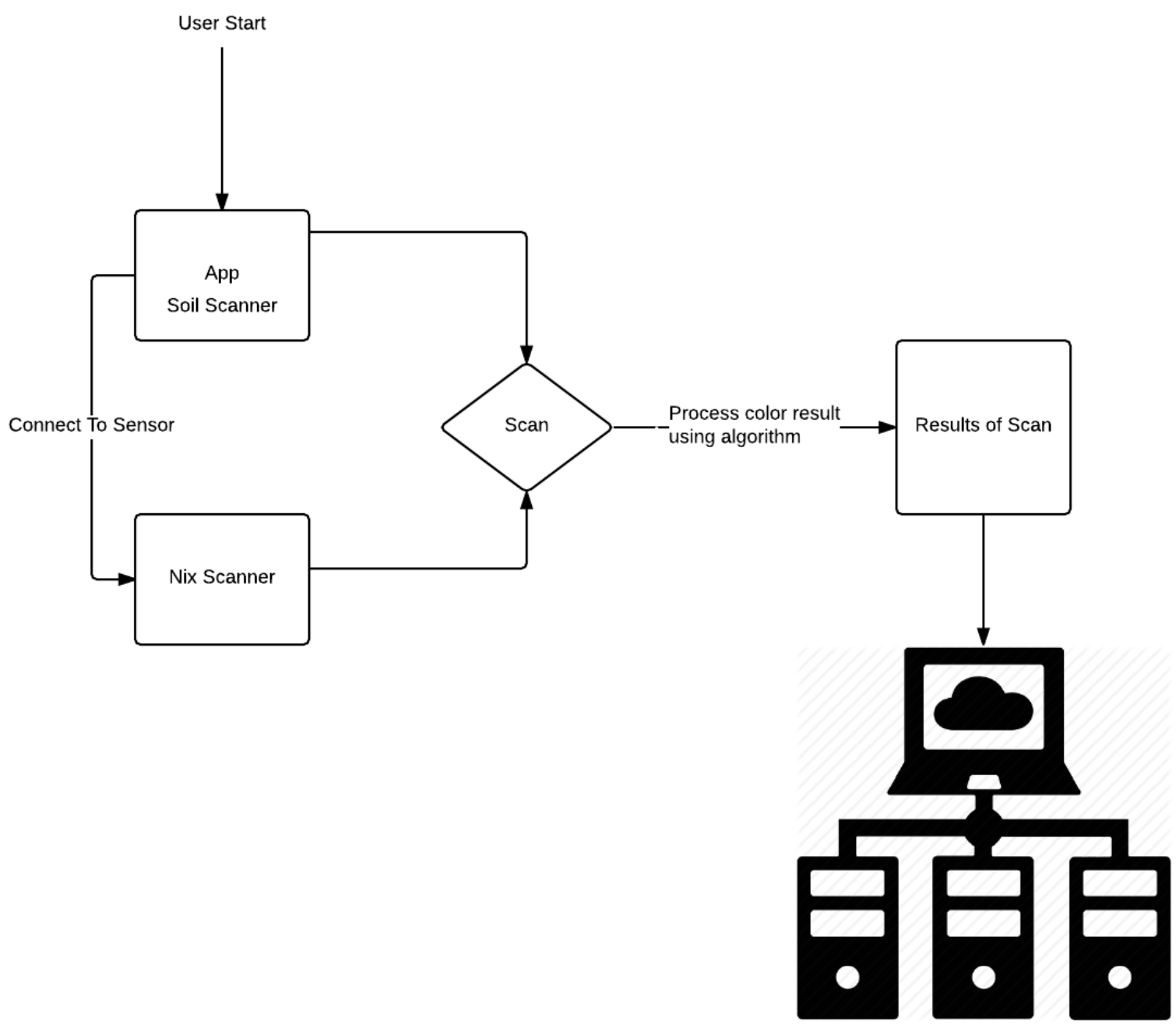

Fig. 1. Functional diagram of the Color Scanner application which shows the process of scanning a soil sample for color from start to finish. 


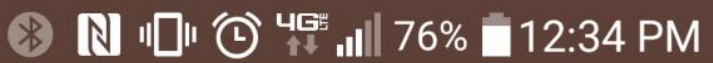

\section{Scan Results}
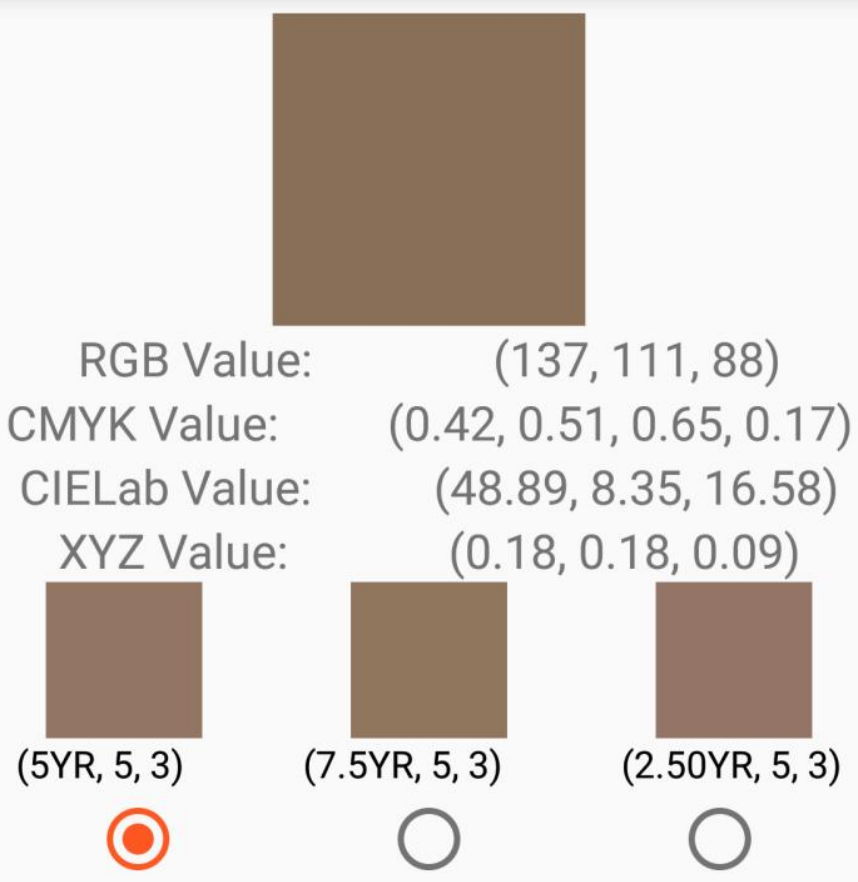

Calculated Distance: 3.1035760191364

Field Mode:

Dry

Location: $\quad(34.674,-82.829) \quad$ GET GPS

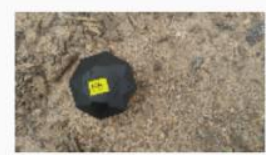

ADD PHOTO

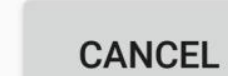

SAVE SCAN

\section{$\triangleleft$}

\section{○}

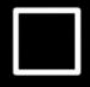

Fig. 2. Example of the Soil Scanner interface that shows all possible color system values for a soil sample and options for "Field Mode," "Dry" soil, GPS location, and attaching a photo of the soil sample. 


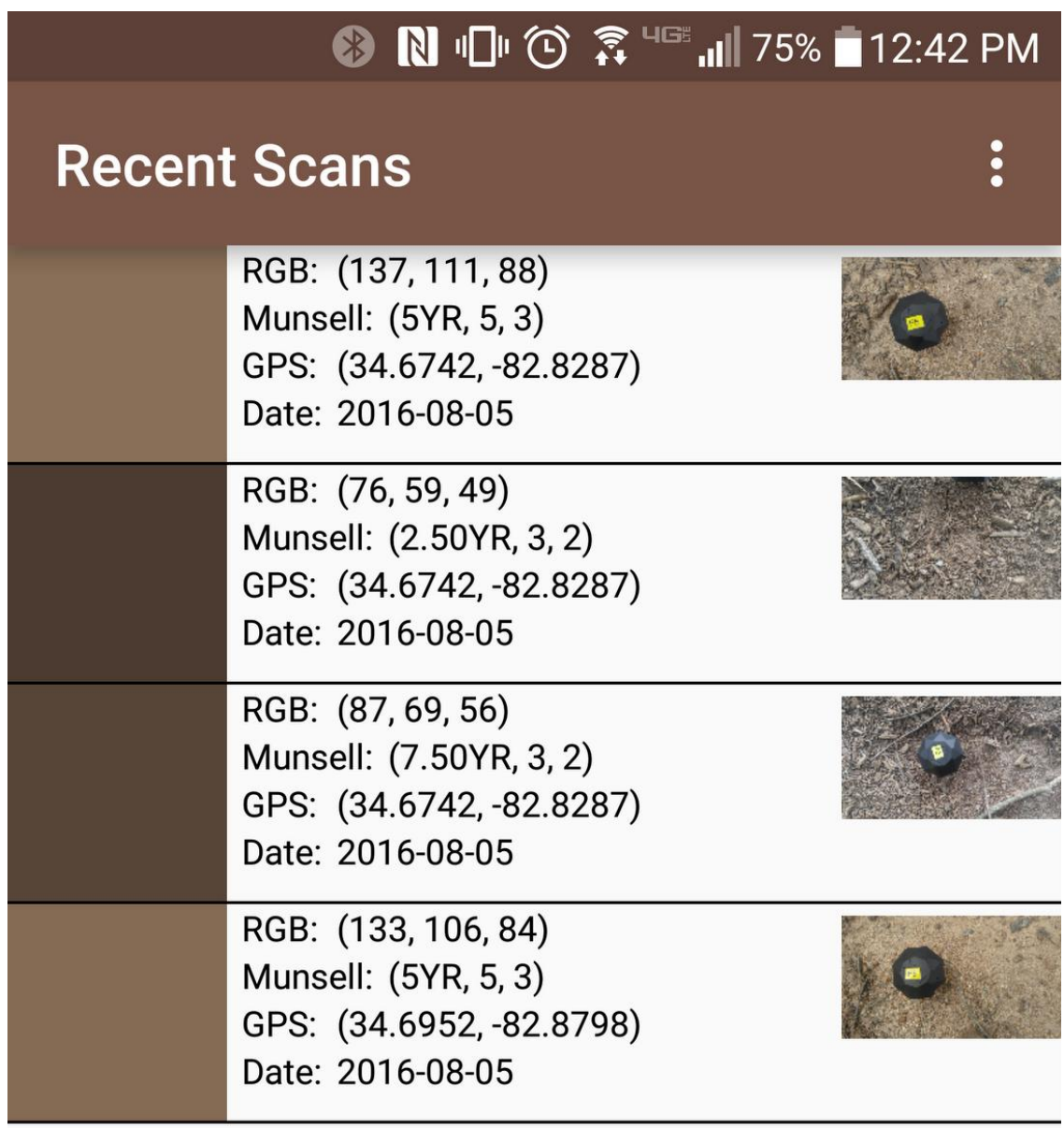

NEW SCAN

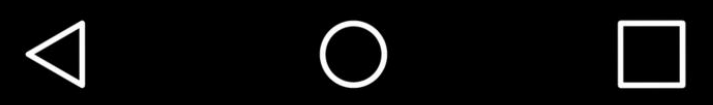

Fig. 3. Example of stored soil scan data using the Soil Scanner application. 


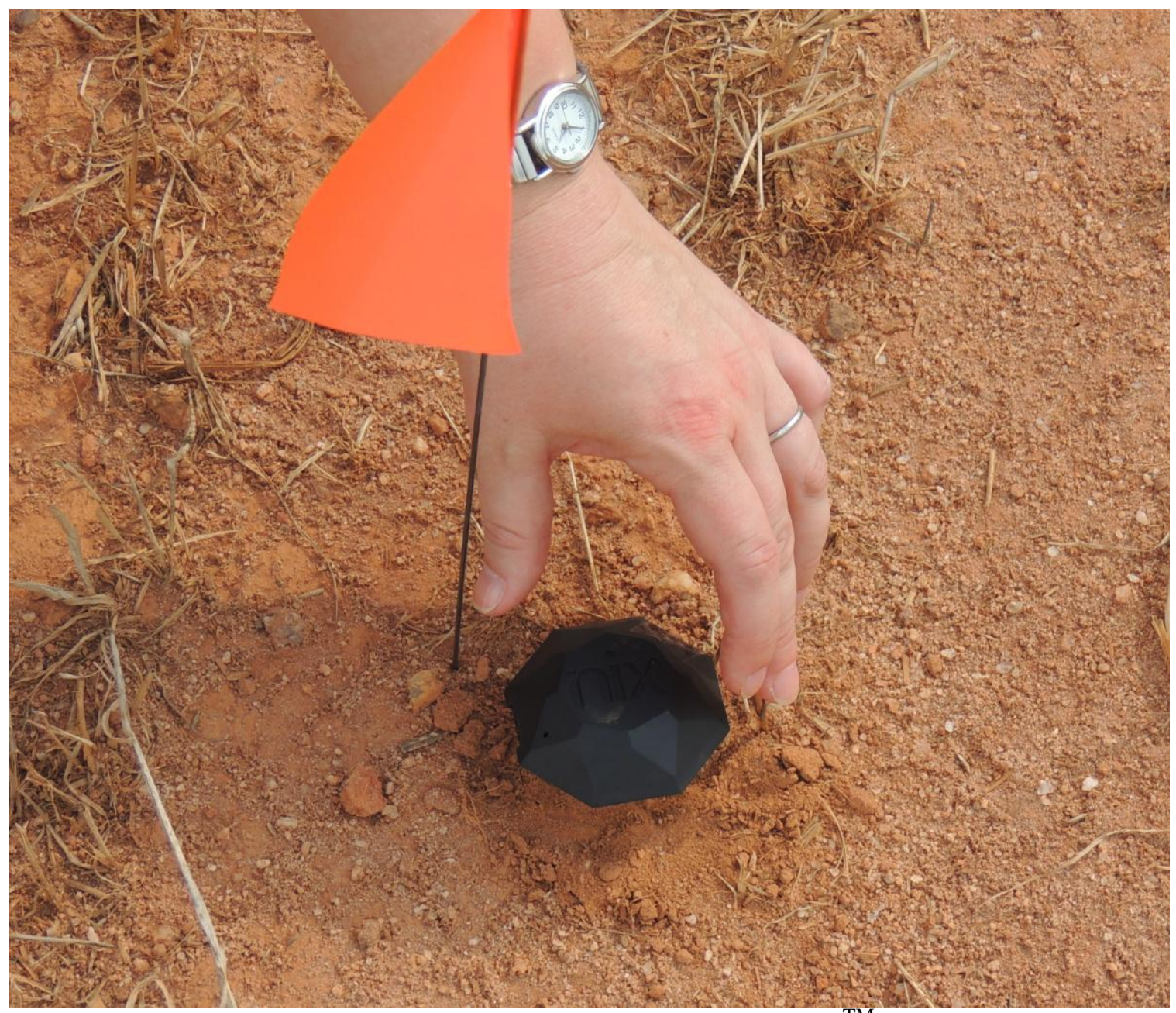

Figure 4. Example of a soil surface being scanned using the $\mathrm{Nix}^{\mathrm{TM}}$ Pro color sensor. 


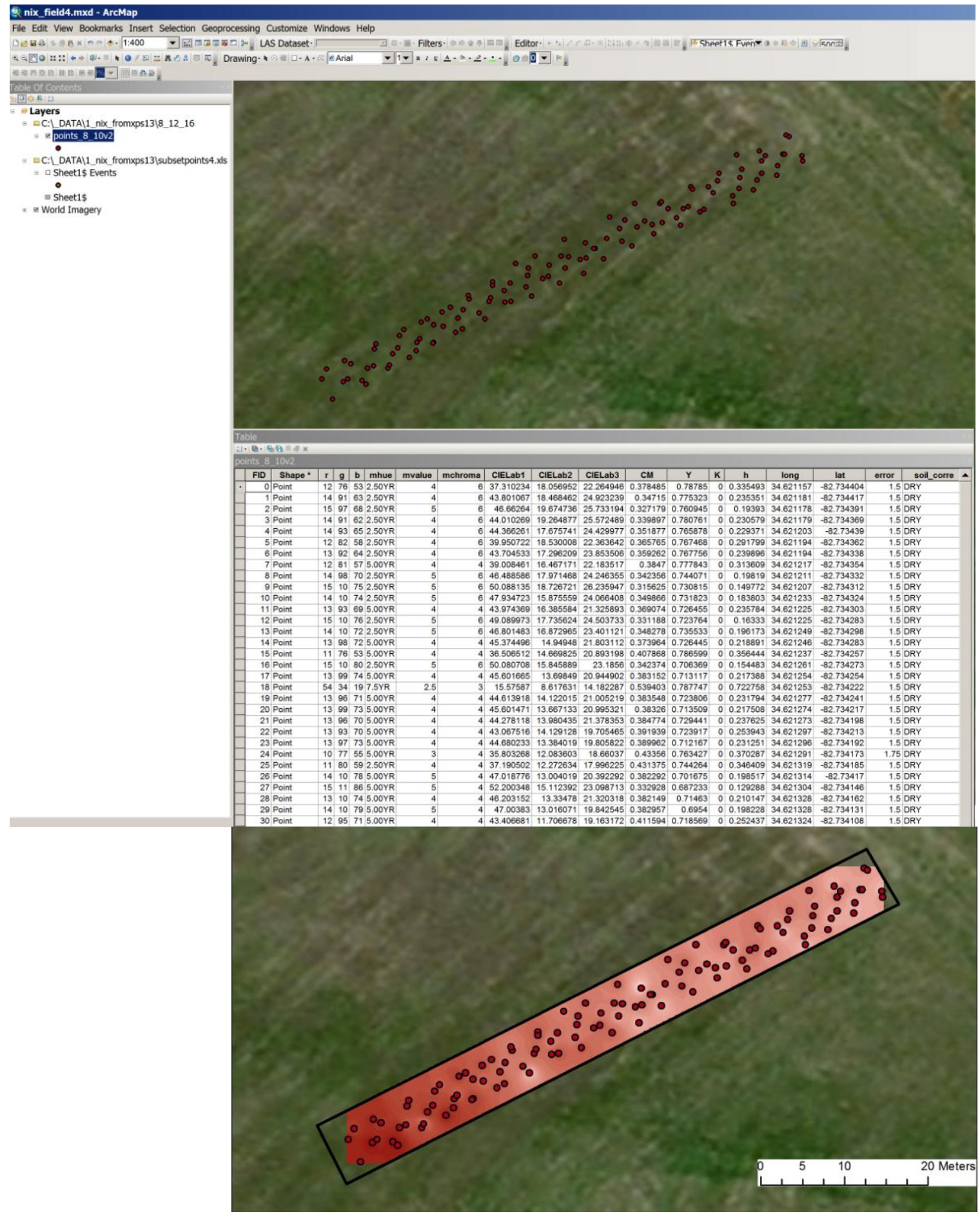

Figure 5. GIS layouts showing: scan locations (top), soil color attributes (middle), and interpolated a* (red) color values using Inverse Distance Weighting (bottom) for the Simpson Agricultural Experiment Station. 


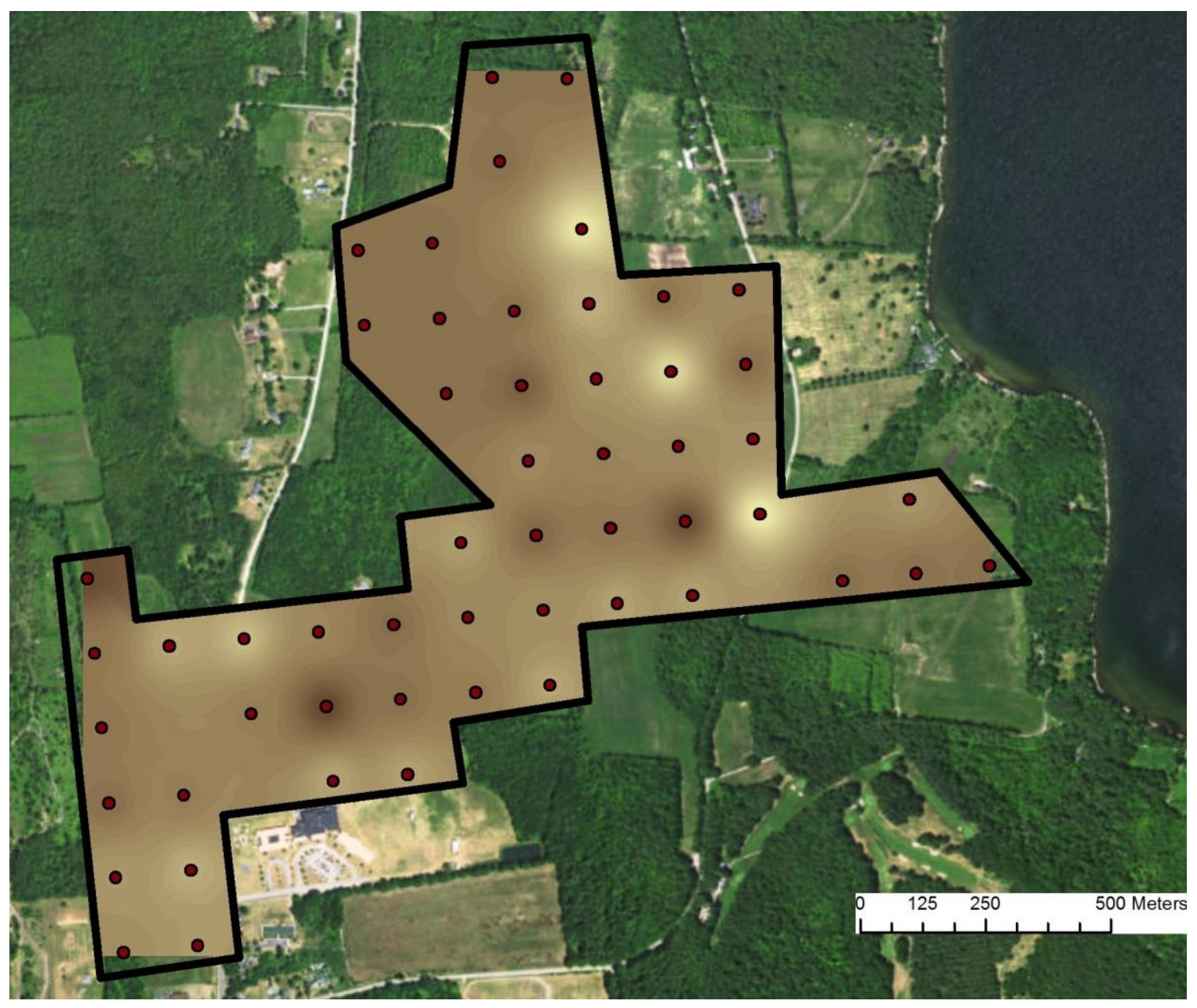

Figure 6. GIS layout showing scan locations and interpolated L* (darkness to lightness) color values using Inverse Distance Weighting for the Willsboro Farm. 
Table 1

Munsell Color Chart and Soil Scanner application color codes for soil horizons of practice soil pit 2 from the Simpson Agricultural Experiment Station in the Munsell Color Chart codes ( $n=31$ soil samples).

\begin{tabular}{|c|c|c|c|c|c|}
\hline $\begin{array}{l}\text { Soil } \\
\text { Horizon }\end{array}$ & $\begin{array}{l}\text { Lower depth } \\
\quad(\mathrm{cm})\end{array}$ & $\begin{array}{c}\text { Munsell Color Chart } \\
\text { Hue (V), Value (V), } \\
\text { Chroma (C) }\end{array}$ & $\begin{array}{c}\text { Soil Scanner first } \\
\text { Munsell set Hue (H), } \\
\text { Value (V), Chroma } \\
\text { (C) }\end{array}$ & $\begin{array}{c}\text { Soil Scanner second } \\
\text { Munsell set Hue (H), Value } \\
\text { (V), Chroma (C) }\end{array}$ & $\begin{array}{l}\text { Soil Scanner third } \\
\text { Munsell set } \\
\text { (Hue, Value, } \\
\text { Chroma) }\end{array}$ \\
\hline & & $\mathrm{C}$ & $\mathrm{H}$ & $\mathrm{H}$ & $\mathrm{H}$ \\
\hline
\end{tabular}

Dry Soil

$\begin{array}{lccccccccccccc}\text { Ap } & 11 & 7.5 \mathrm{YR} & 6 & 4 & 10 \mathrm{YR} & 5 & 4 & 7.5 \mathrm{YR} & 5 & 4 & 2.5 \mathrm{YR} & 5 & 4 \\ \mathrm{Bt} 1 & 28 & 5 \mathrm{YR} & 5 & 8 & 5 \mathrm{YR} & 5 & 6 & 2.5 \mathrm{YR} & 5 & 6 & 7.5 \mathrm{YR} & 5 & 6 \\ \mathrm{Bt} 2 & 59 & 7.5 \mathrm{YR} & 6 & 6 & 2.5 \mathrm{YR} & 5 & 6 & 10 \mathrm{R} & 5 & 6 & 5 \mathrm{YR} & 5 & 6 \\ \mathrm{Bt} 3 & 90+ & 5 \mathrm{YR} & 5 & 6 & 7.5 \mathrm{YR} & 5 & 6 & 10 \mathrm{R} & 4 & 6 & 5 \mathrm{YR} & 5 & 6\end{array}$

Moist Soil

\begin{tabular}{|c|c|c|c|c|c|c|c|c|c|c|c|c|}
\hline Ap & 11 & $5 \mathrm{YR}^{*}$ & 4 & 4 & 7.5YR & 3 & 4 & $5 Y R$ & 3 & 4 & 10YR & 3 \\
\hline Bt1 & 28 & 5 YR & 4 & 6 & $5 Y R$ & 4 & 6 & 7.5YR & 4 & 4 & 10YR & 4 \\
\hline $\mathrm{Bt} 2$ & 59 & $2.5 \mathrm{YR}$ & 4 & 6 & $5 \mathrm{YR}$ & 4 & 6 & $2.5 \mathrm{YR}$ & 4 & 6 & 7.5YR & 4 \\
\hline $\mathrm{Bt} 3$ & $90+$ & 10YR & 4 & 6 & $10 \mathrm{R}$ & 3 & 6 & $5 Y R$ & 4 & 6 & $7.5 \mathrm{YR}$ & 4 \\
\hline
\end{tabular}

Note: Moist soil color was determined by NRCS soil scientists. 
Table 2

Average Euclidean distance between the known Munsell Color Chart codes and the Munsell Color Chart codes determined by the Soil Scanner application for samples gathered from the Simpson Agricultural Experiment Station.

\begin{tabular}{|c|c|c|c|}
\hline $\begin{array}{c}\text { Euclidean } \\
\text { Distance/Standard } \\
\text { Deviation }\end{array}$ & $\begin{array}{l}\text { Munsell vs. } \\
\text { Soil Scanner } \\
\text { first Munsell } \\
\text { set }\end{array}$ & $\begin{array}{l}\text { Munsell vs. Soil } \\
\text { Scanner second } \\
\text { Munsell set }\end{array}$ & $\begin{array}{c}\text { Munsell vs. Soil } \\
\text { Scanner third } \\
\text { Munsell set }\end{array}$ \\
\hline \multicolumn{4}{|c|}{ Dry soil } \\
\hline Distance & 2 & 3 & 3 \\
\hline Std. Dev. & 0.96 & 1.21 & 1.54 \\
\hline \multicolumn{4}{|c|}{ Moist soil } \\
\hline Distance & 2 & 3 & 4 \\
\hline Std. Dev. & 2.06 & 1.97 & 3.28 \\
\hline
\end{tabular}

Note: Euclidean distance refers to the number of color chips away the measured value is from the actual value. 
Table 3

Average Euclidean distance between the known Munsell Color Chart codes and the Munsell Color Chart codes determined by the Soil Scanner application for samples $(n=264)$ gathered from the Willsboro Farm.

\begin{tabular}{lccc}
\hline $\begin{array}{c}\text { Euclidean } \\
\text { Distance/Standard } \\
\text { Deviation }\end{array}$ & $\begin{array}{c}\text { Munsell vs. } \\
\text { Soil Scanner } \\
\text { first Munsell } \\
\text { set }\end{array}$ & $\begin{array}{c}\text { Munsell vs. Soil } \\
\text { Scanner second } \\
\text { Munsell set }\end{array}$ & $\begin{array}{c}\text { Munsell vs. Soil } \\
\text { Scanner third } \\
\text { Munsell set }\end{array}$ \\
\hline & & & \\
Distance & 3 & 4 & 4 \\
Std. Dev. & 1.05 & 1.99 & 2.31 \\
\hline
\end{tabular}

Note: Euclidean distance refers to the number of color chips away the measured value is from the actual value. 